\title{
Microbial Contamination of Date Rutab Collected from the Markets of Al-Hofuf City in Saudi Arabia
}

\author{
Siddig H. Hamad, Farag A. Saleh, and Mutlag M. Al-Otaibi \\ Department of Food Science and Nutrition, College of Agricultural and Food Sciences, King Faisal University, P.O. Box 420, \\ Al-Hofuf 31982, Saudi Arabia \\ Correspondence should be addressed to Siddig H. Hamad, siddighamad@yahoo.com
}

Received 30 October 2011; Accepted 21 December 2011

Academic Editor: Baubak Bajoghli

Copyright ( $\odot 2012$ Siddig H. Hamad et al. This is an open access article distributed under the Creative Commons Attribution License, which permits unrestricted use, distribution, and reproduction in any medium, provided the original work is properly cited.

\begin{abstract}
The microbial contamination of 60 samples from six date cultivars in the rutab stage purchased from different retail outlets in AL-Hofuf City, Saudi Arabia was studied. All samples were found contaminated with aerobic mesophilic bacteria at loads in the order $10^{2}$ to $10^{5} \mathrm{cfu} / \mathrm{cm}^{2}$ with some significant differences among varieties that can be attributed to differences in the weather conditions during rutab season. Also all samples, except only one, were contaminated with molds and yeasts at loads in the order $10^{2}$ to $10^{3} \mathrm{cfu} / \mathrm{cm}^{2}$. Potentially pathogenic Staphylococcus aureus was detected in 57 samples and A. flavus/parasiticus in 13 samples, while coliforms were detected in 39 samples.
\end{abstract}

\section{Introduction}

Date (Phoenix dactylifera L.) is mainly produced in Middle Eastern and North African countries. It is considered an important subsistence food crop in most of these countries, in addition to its high cultural and religious significance. Date fruit production has constantly increased worldwide over the last four decades from 1.8 million tons in 1963 to 6.7 millions in 2003 [1]. Saudi Arabia, with about 830 thousand tons annual production, ranks as the third largest date producer in the world [1]. Rutab (an Arabic name) is a stage of maturity in which the date fruit can be consumed as human food. It is a fresh product that contains 35 to $40 \%$ water and 45 to $48 \%$ sugars (dry matter basis) [2]. Because of its high moisture content, rutab is highly susceptible to microbial growth and spoilage, especially when poor hygienic practices during handling lead to heavy microbial contamination. Microbiological studies on dates are limited, especially in the main countries of production [3-9]. No published work on the microbial contamination of rutab was found.

This present study was undertaken to investigate the microbial contamination of rutab from different date cultivars grown in the Gulf Region in Saudi Arabia.

\section{Materials and Methods}

2.1. Rutab Samples. The rutab samples were purchased from 10 different retail outlets in Al-Hofuf City and represented the most popular six date cultivars grown in the region: $\mathrm{Khu}$ las, Um-Ruhaim, Hilali, Shahal, Tiar, and Megnaz. A total of 60 samples were collected at weekly interval, 10 samples from each cultivar at each sampling time, and microbial analysis was carried out on the same day.

2.2. Microbiological Analysis. Four fruits from each rutab sample were transferred into sterile stomacher bags, $50 \mathrm{~mL}$ sterile peptone water (CM0009, Oxoid, Basingstoke, UK) added, and the fruits washed manually for 2 minutes in this water, then aliquots $(1.0$ or $0.1 \mathrm{~mL})$ were plated in duplicate as 10 -fold dilutions in peptone water (surface area of the 4 fruits was then measured). Three replicates were analyzed for each sample and the average microbial loads calculated and reported as colony-forming units ( $\mathrm{cfu}$ ) per $\mathrm{cm}^{2}$. Aerobic mesophilic bacteria were enumerated on plate count agar (CM0325, Oxoid) incubated at $30^{\circ} \mathrm{C}$ for 2 to 3 days. Coliforms were determined on violet red bile agar plates (VRBA, $\mathrm{CM} 0107$, Oxoid) incubated at $37^{\circ} \mathrm{C}$ for 24 hours. Round, 
TABLE 1: Counts of aerobic mesophilic bacteria contaminating rutab samples $\left(\mathrm{cfu} / \mathrm{cm}^{2}\right)$.

\begin{tabular}{|c|c|c|c|c|c|c|}
\hline Sample & Khulas & Um-Ruhaim & Shahal & Hilali & Tiar & Megnaz \\
\hline 1 & $1.3 \times 10^{4}$ & $1.8 \times 10^{4}$ & $4.5 \times 10^{4}$ & $4.1 \times 10^{3}$ & $4.3 \times 10^{3}$ & $5.2 \times 10^{3}$ \\
\hline 2 & $2.2 \times 10^{3}$ & $4.4 \times 10^{4}$ & $3.8 \times 10^{4}$ & $3.2 \times 10^{3}$ & $3.0 \times 10^{3}$ & $1.9 \times 10^{4}$ \\
\hline 3 & $3.2 \times 10^{3}$ & $2.8 \times 10^{3}$ & $1.5 \times 10^{4}$ & $6.9 \times 10^{3}$ & $6.5 \times 10^{3}$ & $2.0 \times 10^{3}$ \\
\hline 4 & $1.5 \times 10^{3}$ & $5.9 \times 10^{3}$ & $1.8 \times 10^{4}$ & $3.8 \times 10^{4}$ & $1.1 \times 10^{3}$ & $1.1 \times 10^{4}$ \\
\hline 5 & $4.2 \times 10^{4}$ & $2.4 \times 10^{4}$ & $1.5 \times 10^{3}$ & $2.3 \times 10^{5}$ & $3.4 \times 10^{3}$ & $1.1 \times 10^{3}$ \\
\hline 6 & $7.3 \times 10^{2}$ & $2.0 \times 10^{3}$ & $2.6 \times 10^{5}$ & $2.9 \times 10^{3}$ & $2.6 \times 10^{4}$ & $6.7 \times 10^{3}$ \\
\hline 7 & $4.3 \times 10^{3}$ & $3.9 \times 10^{3}$ & $3.7 \times 10^{3}$ & $1.9 \times 10^{5}$ & $5.2 \times 10^{3}$ & $1.8 \times 10^{4}$ \\
\hline 8 & $2.0 \times 10^{4}$ & $3.3 \times 10^{4}$ & $9.1 \times 10^{3}$ & $2.0 \times 10^{5}$ & $5.0 \times 10^{3}$ & $8.0 \times 10^{3}$ \\
\hline 9 & $4.2 \times 10^{4}$ & $1.3 \times 10^{3}$ & $2.6 \times 10^{4}$ & $1.6 \times 10^{5}$ & $1.5 \times 10^{3}$ & $4.8 \times 10^{3}$ \\
\hline 10 & $3.7 \times 10^{3}$ & $5.5 \times 10^{3}$ & $1.6 \times 10^{4}$ & $1.8 \times 10^{5}$ & $1.0 \times 10^{5}$ & $5.8 \times 10^{3}$ \\
\hline Mean* & $3.77^{\mathrm{b}}$ & $3.88^{\mathrm{b}}$ & $4.24^{\mathrm{ab}}$ & $4.54^{\mathrm{a}}$ & $3.75^{\mathrm{b}}$ & $3.78^{\mathrm{b}}$ \\
\hline
\end{tabular}

${ }^{*} \log _{10}$; means with the same letter are not significantly different $(P \leq 0.05)$.

purple-red colonies $(0.5-2 \mathrm{~mm}$ diameter) surrounded by purple-red haloes on VRBA plates were counted as coliforms. The presence of Escherichia coli O157 among coliforms detected on VRBA plates was tested using the Escherichia coli O157 Latex Test (DR0620, Oxoid). Yeasts and molds were counted on potato dextrose agar plates (CM0139, Oxoid) incubated at $30^{\circ} \mathrm{C}$ for 3 days. Staphylococcus aureus was enumerated on Staphylococcus medium no. 110 (CM0145, Oxoid) incubated at $35-37^{\circ} \mathrm{C}$ for $24-48$ hours (colonies with yellow orange pigment and clearing zone around them) and identified using the Staphylase Test (DR0595, Oxoid). Aspergillus flavus/parasiticus was detected and enumerated on Aspergillus flavus-parasiticus agar (CM0731, Oxoid) incubated at $30^{\circ} \mathrm{C}$ for 48 hours. Colonies that form bright orangeyellow pigments on the colony reverse were counted as Aspergillus flavus/parasiticus.

2.3. Statistical Analysis. A multiple comparison statistical procedure using Fisher's least significant difference test (SAS software, version 6.11) was used to determine the significance of differences among rutab cultivars to microbial spoilage at significance levels of $P \leq 0.05$ [10].

\section{Results and Discussion}

All rutab samples from the six date varieties tested were found contaminated with aerobic mesophilic bacteria at loads in the order $10^{2}$ to $10^{5} \mathrm{cfu} / \mathrm{cm}^{2}$ (Table 1). The levels of contamination with these microorganisms are indices of the general microbiological quality and give idea about the expected shelf lives of the foods concerned. The highest levels of contamination with these bacteria were found in Hilali. Five samples from this variety had loads of $1.6 \times 10^{5}$ to $2.3 \times$ $10^{5}$, one sample a load of $3.8 \times 10^{4}$, and 4 samples $2.9 \times$ $10^{3}$ to $6.9 \times 10^{3} \mathrm{cfu} / \mathrm{cm}^{2}$. Shahal samples had generally lower loads of contamination than Hilali, with one sample having $2.6 \times 10^{5}, 6$ samples $1.5 \times 10^{4}$ to $4.5 \times 10^{4}$, and 3 samples $1.5 \times 10^{3}$ to $9.1 \times 10^{3} \mathrm{cfu} / \mathrm{cm}^{2}$. The loads of the other 4 varieties were still lower and comparable to each other. Um
Ruhaim had loads of $1.8 \times 10^{4}$ to $4.4 \times 10^{4}$ in 4 samples, and $1.3 \times 10^{3}$ to $5.6 \times 10^{3}$ in 6 samples, Khulas had $1.3 \times 10^{4}$ to $4.2 \times 10^{4}$ in 4 samples, and $1.5 \times 10^{3}$ to $4.3 \times 10^{3} \mathrm{cfu} / \mathrm{cm}^{2}$ in 6 samples, Tiar had $1.0 \times 10^{5}$ in one sample, $2.6 \times 10^{4}$ in one sample, and $1.1 \times 10^{3}$ to $6.5 \times 10^{3} \mathrm{cfu} / \mathrm{cm}^{2}$ in 8 samples, while Megnaz had $1.1 \times 10^{4}$ to $1.9 \times 10^{4}$ in 3 samples and $1.1 \times 10^{3}$ to $8.0 \times 10^{3} \mathrm{cfu} / \mathrm{cm}^{2}$ in 7 samples. The level of Hilali contamination was significantly higher than that of Khulas, Um Ruhaim, Tiar, and Megnaz; it was also higher than the level of Shahal, but the difference was not significant. On the other hand, the level of contamination of Shahal was higher than that of Khulas, Um Ruhaim, Tiar, and Megnaz, but the difference was not significant. The levels of contamination of Khulas, Um-Ruhaim, Tiar and Megnaz were quite similar (Table 1). The differences in the levels of contamination with aerobic mesophilic bacteria among these rutab samples may be attributed to differences in environmental temperatures during rutab season. Khulas, Um Ruhaim, Tiar, and Megnaz are early maturing varieties and they were sampled and analyzed by the end of August where the temperatures in Saudi Arabia were above $40^{\circ} \mathrm{C}$, thus the spread of mesophilic bacteria is expected to be limited. Shahal matures in mid-August and was sampled and analyzed mid-September, where the temperatures start to drop below $40^{\circ} \mathrm{C}$, while Hilali is a late maturing variety and its samples in this study were collected and analyzed in October where the temperatures were in the thirties, and hence the mesophilic bacteria are supposed to dominate in the environment.

Almost all samples were contaminated with varying loads of molds and yeasts (Table 2), which are generally spoilage organisms, although some of them could be pathogenic. Shahal and Hilali showed the highest levels of contaminations with molds and yeasts. One Shahal sample had $1.9 \times 10^{4}$, 2 samples $2.3 \times 10^{3}$ and $4.6 \times 10^{3}$, and 7 samples $1.7 \times 10^{2}$ to $7.8 \times 10^{2} \mathrm{cfu} / \mathrm{cm}^{2}$. One Hilali sample had $1.1 \times 10^{4}, 3 \mathrm{sam}-$ ples $1.2 \times 10^{3}$ to $5.9 \times 10^{3}$, and 6 samples $1.1 \times 10^{2}$ to $4.7 \times 10^{2} \mathrm{cfu} / \mathrm{cm}^{2}$. Two Um Ruhaim samples had $1.8 \times 10^{3}$ and $2.0 \times 10^{3}$, and 8 samples $2.0 \times 10^{2}$ to $6.9 \times 10^{2}$, cfu/ $\mathrm{cm}^{2}$, while 3 Khulas samples had $1.0 \times 10^{3}$ to $1.2 \times 10^{3}$, 6 samples $2.1 \times 10^{2}$ to $4.8 \times 10^{2} \mathrm{cfu} / \mathrm{cm}^{2}$, and one sample 
TABLE 2: Counts of yeasts and molds contaminating rutab samples $\left(\mathrm{cfu} / \mathrm{cm}^{2}\right)$.

\begin{tabular}{lcccccc}
\hline Sample & Khulas & Um-Ruhaim & Shahal & Hilali & Tiar & $2.6 \times 10^{2}$ \\
\hline 1 & $4.8 \times 10^{2}$ & $2.0 \times 10^{3}$ & $7.8 \times 10^{2}$ & $2.5 \times 10^{2}$ & $5.2 \times 10^{2}$ \\
2 & $3.3 \times 10^{2}$ & $2.4 \times 10^{2}$ & $1.9 \times 10^{4}$ & $1.1 \times 10^{4}$ & $2.3 \times 10^{2}$ & $2.2 \times 10^{2}$ \\
3 & $2.1 \times 10^{2}$ & $3.0 \times 10^{2}$ & $1.7 \times 10^{2}$ & $4.7 \times 10^{2}$ & $2.2 \times 10^{2}$ & $1.7 \times 10^{2}$ \\
4 & $1.2 \times 10^{3}$ & $2.0 \times 10^{2}$ & $3.7 \times 10^{2}$ & $5.9 \times 10^{3}$ & $1.5 \times 10^{3}$ & $1.3 \times 10^{2}$ \\
5 & n.d. & $6.9 \times 10^{2}$ & $2.2 \times 10^{2}$ & $1.2 \times 10^{3}$ & $3.3 \times 10^{2}$ & $1.4 \times 10^{3}$ \\
6 & $1.1 \times 10^{3}$ & $3.2 \times 10^{2}$ & $4.6 \times 10^{3}$ & $3.4 \times 10^{2}$ & $2.2 \times 10^{2}$ \\
7 & $2.1 \times 10^{2}$ & $1.8 \times 10^{3}$ & $2.3 \times 10^{3}$ & $1.2 \times 10^{3}$ & $2.6 \times 10^{2}$ \\
8 & $4.5 \times 10^{2}$ & $3.4 \times 10^{2}$ & $5.2 \times 10^{2}$ & $1.8 \times 10^{2}$ & $1.3 \times 10^{2}$ \\
9 & $2.1 \times 10^{2}$ & $5.3 \times 10^{2}$ & $3.3 \times 10^{2}$ & $2.3 \times 10^{2}$ & $3.2 \times 10^{2}$ \\
10 & $1.0 \times 10^{3}$ & $4.5 \times 10^{2}$ & $3.9 \times 10^{2}$ & $1.1 \times 10^{2}$ & $1.7 \times 10^{2}$ & $2.4 \times 10^{2}$ \\
\hline Mean* & $2.39^{\mathrm{a}}$ & $2.70^{\mathrm{a}}$ & $2.92^{\mathrm{a}}$ & $2.82^{\mathrm{a}}$ & $2.41^{\mathrm{a}}$ \\
\hline
\end{tabular}

${ }^{*} \log _{10}$; means with the same letter are not significantly different $(P \leq 0.05)$. n.d.: not detected.

TABLE 3: Counts of Staphylococcus aureus contaminating rutab samples $\left(\mathrm{cfu} / \mathrm{cm}^{2}\right)$.

\begin{tabular}{|c|c|c|c|c|c|c|}
\hline Sample & Khulas & Um-Ruhaim & Shahal & Hilali & Tiar & Megnaz \\
\hline 1 & $1.9 \times 10^{2}$ & $1.5 \times 10^{3}$ & $3.5 \times 10^{2}$ & 41 & 8 & 39 \\
\hline 2 & $1.2 \times 10^{2}$ & $2.4 \times 10^{2}$ & $3.0 \times 10^{2}$ & 52 & nd & 86 \\
\hline 3 & $2.4 \times 10^{2}$ & 27 & $1.6 \times 10^{3}$ & 99 & 15 & 24 \\
\hline 4 & 77 & 64 & $3.8 \times 10^{2}$ & $1.4 \times 10^{2}$ & 5 & 58 \\
\hline 5 & 58 & $2.6 \times 10^{2}$ & $1.0 \times 10^{3}$ & $4.5 \times 10^{2}$ & 17 & 30 \\
\hline 6 & $1.5 \times 10^{2}$ & $1.0 \times 10^{3}$ & 40 & 66 & 86 & $1.3 \times 10^{2}$ \\
\hline 7 & $1.1 \times 10^{3}$ & 28 & $3.3 \times 10^{2}$ & $1.3 \times 10^{2}$ & 13 & $2.2 \times 10^{2}$ \\
\hline 8 & $3.5 \times 10^{2}$ & $2.7 \times 10^{2}$ & $2.9 \times 10^{3}$ & 45 & 43 & 32 \\
\hline 9 & $4.0 \times 10^{2}$ & $2.4 \times 10^{2}$ & 47 & 23 & nd & $2.0 \times 10^{2}$ \\
\hline 10 & $4.4 \times 10^{2}$ & $1.9 \times 10^{3}$ & 45 & 25 & nd & 76 \\
\hline Mean* & $2.3^{\mathrm{ab}}$ & $2.37^{\mathrm{ab}}$ & $2.47^{a}$ & $1.85^{\mathrm{b}}$ & $0.87^{c}$ & $1.83^{\mathrm{b}}$ \\
\hline
\end{tabular}

${ }^{*} \log _{10}$; means with the same letter are not significantly different $(P \leq 0.05)$.

undetectable level. In case of Tiar, only one sample showed a level of contamination of $1.5 \times 10^{3}$ and the contamination of the other 9 samples was in the range $1.3 \times 10^{2}$ to 3.3 $\times 10^{2} \mathrm{cfu} / \mathrm{cm}^{2}$. The contamination of Megnaz samples was $1.4 \times 10^{3}$ in one sample and $1.3 \times 10^{2}$ to $5.2 \times 10^{2} \mathrm{cfu} / \mathrm{cm}^{2}$ in 9 samples. Contamination of Khulas, Um Ruhaim, Tiar, and Megnaz with molds and yeasts was generally lower than that of Hilali and Shahal, but the differences were not significant (Table 2).

Microbial contaminations in the order $10^{5} \mathrm{cfu} / \mathrm{g} \cdot \mathrm{cm}^{2} \cdot \mathrm{mL}$ can be regarded as high since signs of microbial spoilage start to appear in most foods at loads of about $10^{6} \mathrm{cfu} / \mathrm{g} \cdot \mathrm{cm}^{2} \cdot \mathrm{mL}$ [11]. Rutab with such high microbial contamination levels is expected to have a short shelf life if kept at room temperature. This high level of contamination was mainly found in Hilali where 5 of the 10 samples tested contained more than $10^{5} \mathrm{cfu} / \mathrm{cm}^{2}$ (Table 1$)$.

With respect to pathogenic microorganisms, all samples of Khulas, Um-Ruhaim, Shahal, Hilali, and Megnaz and 7 samples of Tiar were found contaminated with the potential food poisoning bacterium Staphylococcus aureus (Table 3). The highest level of contamination with this bacterium was in Shahal, followed by Um Ruhaim, then Khulas but the differences between the three were not significant. The level of contamination of Hilali and Megnaz was significantly lower than that of Shahal, Um Ruhaim, and Khulas and the level of contamination of Tiar was still lower than all other samples with significant difference from all of them (Table 3). Rutab in Saudi Arabia is harvested manually; thus it seems that contamination of the date fruits with this bacterium came mainly from workers, and differences in the degree of contamination may be attributed to differences in the hygienic status of these workers. Staphylococcus aureus can infect and grow in wounds on the hands of workers inevitably caused during harvesting by the sharp and strong ends of the leaves of the palm tree.

Coliforms were found in 39 out of the 60 samples analyzed, that is, $65 \%$ of the samples studied (Table 4 ). Their rate of occurrence was similar in 5 cultivars ranging between 6 and 8 contaminated samples, while in Khulas only 4 samples were found contaminated. The loads were relatively low reaching the range of $10^{2} \mathrm{cfu} / \mathrm{g}$ in only 4 samples. The source of contamination was most likely the workers who harvested rutab manually. No Escherichia coli $\mathrm{O} 157$ was detected among these coliforms.

The potential mycotoxin producing molds $A$. flavus and A. parasiticus were found in 13 out of the 60 samples analyzed, that is, $21.7 \%$ contaminated samples (results not 
TABLE 4: Counts of coliforms $\left(\mathrm{cfu} / \mathrm{cm}^{2}\right)$ contaminating rutab samples.

\begin{tabular}{|c|c|c|c|c|c|c|}
\hline Sample & Khulas & Um Ruhaim & Shahal & Hilali & Tiar & Megnaz \\
\hline 1 & 83 & 39 & 37 & n.d. & 91 & 99 \\
\hline 2 & 46 & $9.1 \times 10^{2}$ & 43 & $1.7 \times 10^{2}$ & nd & 61 \\
\hline 3 & n.d. & n.d. & n.d. & 7 & nd & 30 \\
\hline 4 & 4 & 71 & 41 & 9 & 42 & nd \\
\hline 5 & n.d. & 2 & n.d. & 2 & 35 & 86 \\
\hline 6 & n.d. & 10 & 20 & 20 & 28 & nd \\
\hline 7 & $3.0 \times 10^{2}$ & n.d. & 9 & n.d. & nd & 32 \\
\hline 8 & n.d. & $1.1 \times 10^{2}$ & 41 & n.d. & 39 & 93 \\
\hline 9 & n.d. & n.d. & n.d. & 11 & nd & 11 \\
\hline 10 & n.d. & 2 & 2 & 2 & 37 & 10 \\
\hline
\end{tabular}

n.d. = not detected.

shown). They were detected in 2 Khulas, 3 Um-Ruhaim, 4 Shahal, and 4 Hilali but none in Tiar or Megnaz samples. The loads were generally low; the highest was $60 \mathrm{cfu} / \mathrm{cm}^{2}$ in one sample. In spite of their low loads in the samples, if these molds find appropriate conditions for growth and mycotoxin production, the situation can be hazardous.

Microbiological information on the quality of dates is limited, especially in the main countries of production. The level of contamination of most rutab samples in this present study may be considered satisfactory in comparison to levels reported for other fruits such as grapes with $10^{7}$ yeasts $\mathrm{g}^{-1}$, and strawberries, raspberries, and blackberries with $10^{4}$ to $10^{6} \mathrm{~g}^{-1}$ yeasts, up to $10^{4} \mathrm{~g}^{-1}$ molds, and $10^{5}$ to $10^{6} \mathrm{~g}^{-1} \mathrm{bac}-$ teria [12]. The few reports on the microbiology of date fruits were mainly on tamr (Arabic name for fully mature date fruits). A study on the microbial spoilage of rutab showed that spoilage is mainly caused by lactic acid bacteria, yeasts, and molds [7], while the microbial spoilage of tamr is caused by yeasts, molds, and bacteria [8]. Tamr with moisture level raised to $27-30 \%$, inoculated with yeast suspensions, and incubated at $25^{\circ} \mathrm{C}$ was spoiled in 5 days [5]. Colony counts of soft dates in the tamr stage of the order $10^{4} \mathrm{cfu} / \mathrm{g}$ lactic acid bacteria and $10^{2} \mathrm{cfu} / \mathrm{g}$ yeasts were reported [9]. Loose dates were found contaminated with $S$. aureus and aerobic colony counts of $6.3 \times 10^{5} \mathrm{cfu} / \mathrm{g}$ [6]. Date (tamr) samples purchased in stores within Greater Glasgow were found contaminated with up to $10^{4} \mathrm{cfu} / \mathrm{g}$ aerobic mesophilic bacteria, up to $3.4 \times$ $10^{3} \mathrm{cfu} / \mathrm{g}$ coliforms, and up to $6.9 \times 10^{4} \mathrm{cfu} / \mathrm{g}$ yeasts and molds [4]. These authors also detected A. flavus/parasiticus, Bacillus cereus, E. coli, and S. aureus in some samples. No published work on the microbial contamination of rutab was found in the literature cited.

\section{Acknowledgment}

The authors thank the Deanship of Scientific Research, King Faisal University, Saudi Arabia for the financial support of this work.

\section{References}

[1] W. Erskine, A. T. Moustafa, A. E. Osman et al., "Date palm in the GCC countries of the Arabian Peninsula 1-7," July 2008, http://www.icarda.cgiar.org/Facelift.htm.
[2] W. H. Barreveld, Date Palm Production. FAO Agricultural Services Bulletin, vol. 101, Food and Agriculture Organization, Rome, Italy, 1993.

[3] A. H. Abu-Zinada and M. I. Ali, "Fungi associated with dates in Saudi Arabia," Journal of Food Protection, vol. 45, no. 9, pp. 842-844, 1982.

[4] K. E. Aidoo, R. F. Tester, J. E. Morrison, and D. MacFarlane, "The composition and microbial quality of pre-packed dates purchased in Greater Glasgow," International Journal of Food Science and Technology, vol. 31, no. 5, pp. 433-438, 1996.

[5] H. R. Bolin, A. D. King, W. L. Stanely, and L. Jurd, "Antimicrobial protection of moisturized Deglet Noor dates," Applied Microbiology, vol. 4, pp. 799-802, 1972.

[6] M. R. El-Sherbeeny, M. Fahmi Saddik, and F. L. Bryan, "Microbiological profiles of foods served by street vendors in Egypt," International Journal of Food Microbiology, vol. 2, no. 6, pp. 355-364, 1985.

[7] S. H. Hamad, "Microbial spoilage of date rutab collected from the markets of Al-Hofuf City in the Kingdom of Saudi Arabia," Journal of Food Protection, vol. 71, no. 7, pp. 1406-1411, 2008.

[8] A. A. Kader, "Recommendations for maintaining postharvest quality," May 2007, http://postharvest.ucdavis.edu.

[9] A. Nussinovitch, B. Rosen, H. Salik, and I. J. Kopelman, "Effect of heating media on the microbiology and shelf life of heat pasteurized soft dates," Lebensmittel-Wissenschaft und-Technologie, vol. 22, pp. 245-247, 1989.

[10] R. G. Peterson, Design and Analysis of Experiments, Marcel Dekker, New York, USA, 1985.

[11] B. Ray, Fundamental Food Microbiology, CRC Press, Boca Raton, Fla, USA, 3rd edition, 2004.

[12] B. M. Lund and A. L. Snowdon, "Fresh and processed fruits," in The Microbiological Safety and Quality of Food, B. M. Lund, T. C. Baird-Parker, and G. W. Gould, Eds., vol. 1, Aspen, Gaithersburg, Md, USA, 2000. 

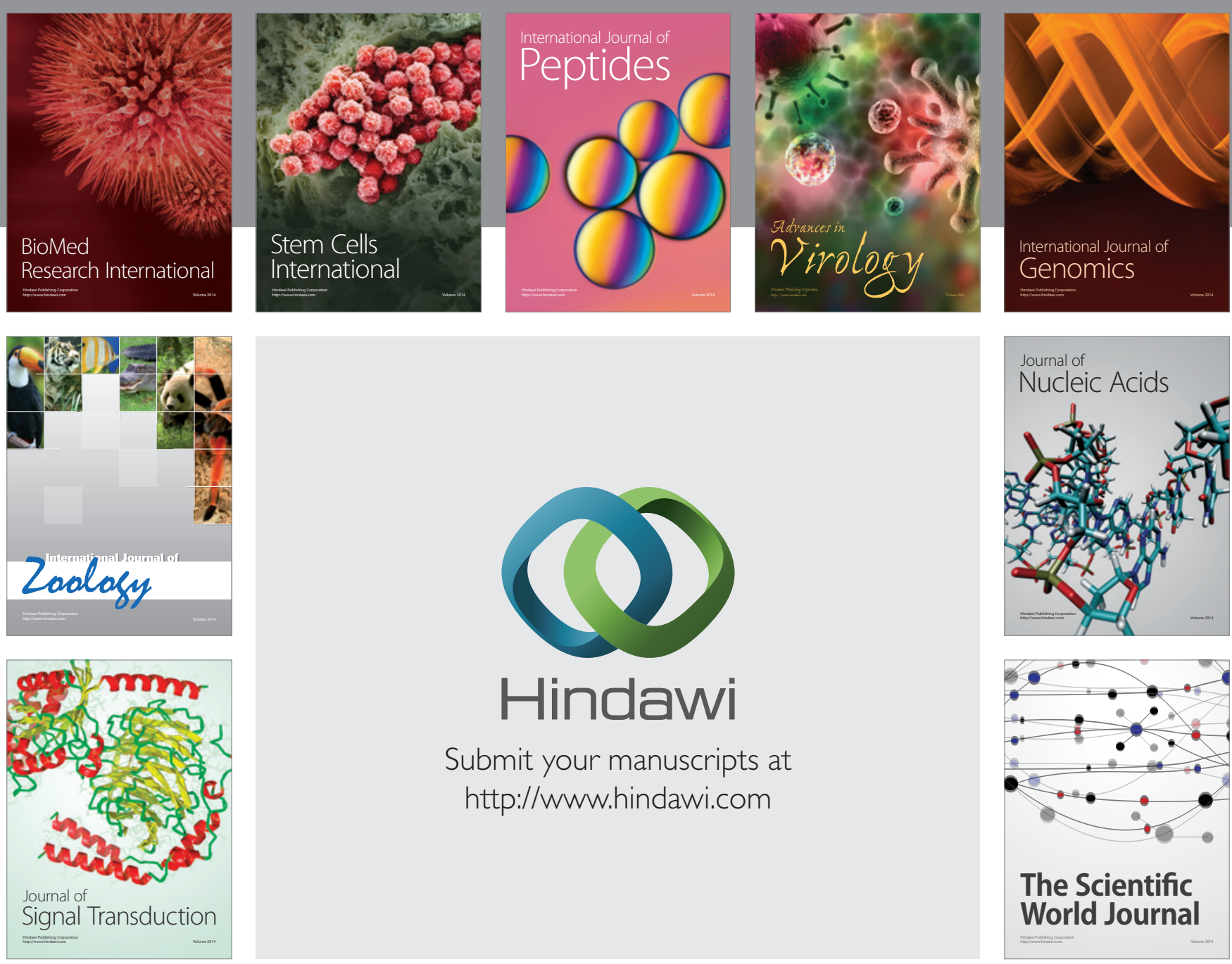

Submit your manuscripts at

http://www.hindawi.com
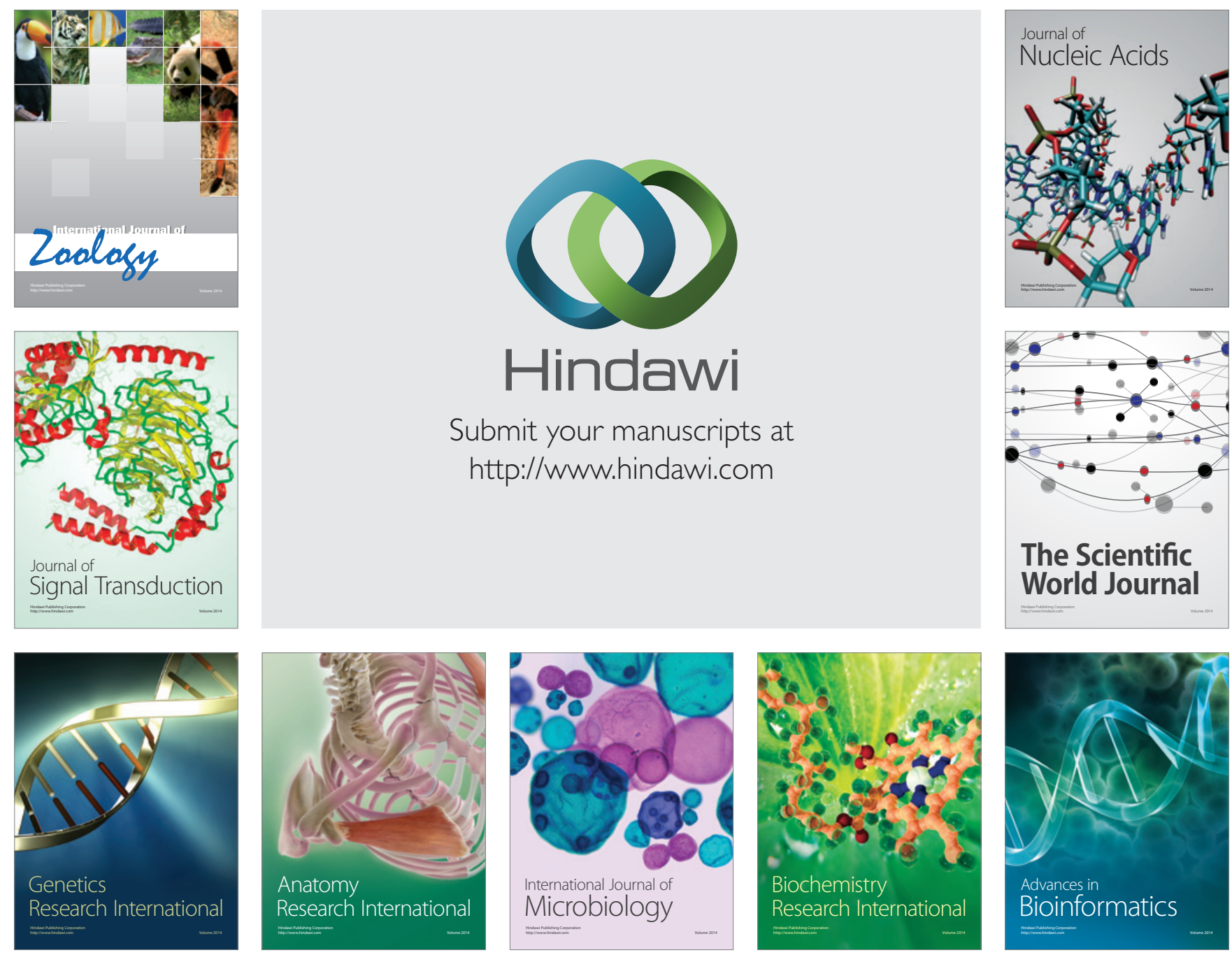

The Scientific World Journal
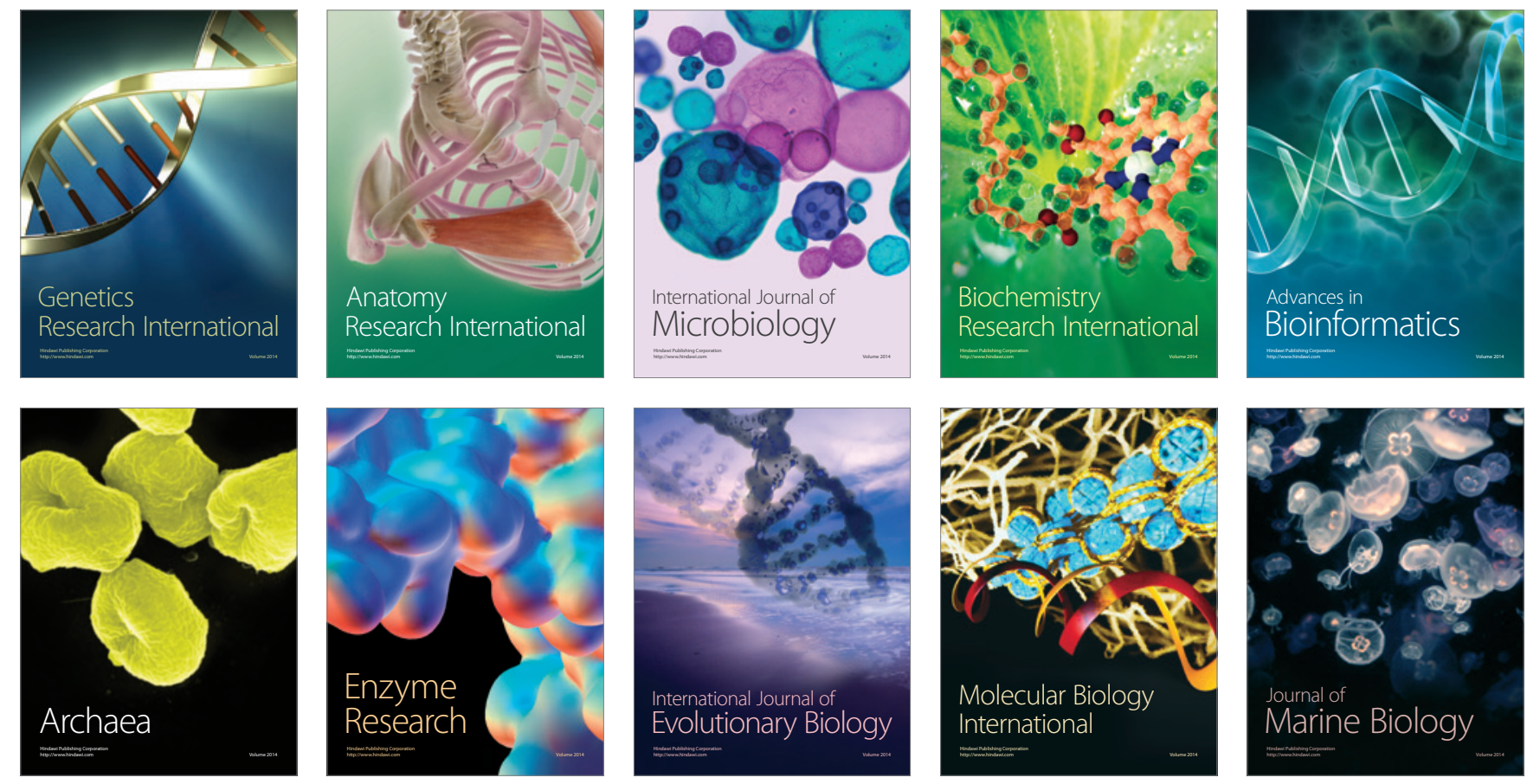